\title{
Die helende krag van regverdige vergifnis, sonder kondonering van onreg
}

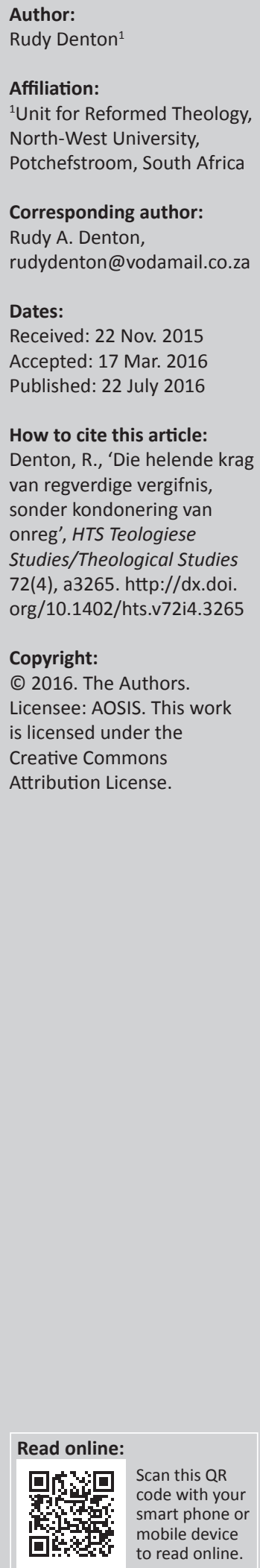

The healing power of just forgiveness, without excusing injustice. Justice is closely related to forgiveness and the extent of the injustice gap experienced depends on how much or how little personal justice a wounded person desires. The experience of forgiveness includes two diverse forms of forgiveness: decisional and emotional forgiveness. Decisional forgiveness is controlling humans' behavioural intentions, while emotional forgiveness replaces negative, unforgiving emotions with positive, other-orientated emotions. A victim may make a decision to forgive, but never feels emotional peace about the decision to forgive. Both decisional and emotional forgiveness are experienced internally within a wounded person and depends on the social context of the transgression and the response to it. Justice can narrow the injustice gap, but rarely closes it, while forgiveness can heal the pain within the injustice gap. The sense of desired justice is to some degree justifiable, but by granting decisional forgiveness and experiencing emotional forgiveness a wounded person can slow down if not stop ruminating vengeful thoughts. Christians can forgive transgression and wrongdoing because they are responding in gratitude to God's mercy, loving-kindness and forgiveness through Jesus' death on the cross. God guides Christian believers through the example of Jesus's humility to forgive wrongdoing and ultimately grow spiritually when Jesus requires decisional forgiveness and desires emotional forgiveness between victim and offender. Forgiveness is based on God's forgiveness, while humans tend to both forgive and also pursue justice without excusing injustice. Humans are in their own power incapable of justly forgiving transgression, but God can guide people through the Holy Spirit to just forgiveness.

\section{Inleiding}

Mense maak foute, benader die wêreld verskillend en is uitgelewer aan hul eie swakhede, persoonlikhede, gedrag en behoeftes. Gekombineer met die alledaagse leefwêreld ervaar mense dikwels konflik, frustrasies, verwonding en ongeregtigheid, wat intense pyn en diep wonde kan veroorsaak. Vir die verwonding deur onreg kan vergifnis egter tot mense se gesondheid, geluk en vrede bydra. Vergifnis is een van die eerste stappe tot genesing wanneer mense probeer om na ' $n$ 'n pynlike of traumatiese ervaring van onreg met hul lewens voort te gaan. Die ervaring van onreg in relasionele kontekste verhoog die spanning tussen geregtigheid en vergifnis. Onreg aktiveer die behoefte aan weerwraak en vergelding vir die vernedering en pyn wat ervaar word. Verwonde mense ervaar dikwels 'n onreg-gaping (injustice gap) en probeer persoonlike geregtigheid najaag om die onreg-gaping te verklein.

Die hooffokus van hierdie artikel is om die helende krag van regverdige vergifnis, sonder kondonering of verskoning vir die onreg wat plaasgevind het te verken. Vergifnis en geregtigheid kan egter in balans gehou word deur die verstandhouding dat die mens (slagoffer en oortreder) deur Christus verloste en begenadigde sondaars is. Christene kan regverdige vergifnis in relasionele konteks nastreef wanneer hulle die ervaring van onreg verstaan en dit binne die konteks van sonde en verlossing onderskei, sonder die kondonering of verskoning vir die onreg wat gepleeg is.

\section{Geregtigheid en onreg}

Mense met 'n Christelike wêreldbeskouing moet geregtigheid vestig, wat vryheid en gelyke geleenthede vir almal verseker. Sonder geregtigheid kan oortreders voortgaan om onreg te pleeg, verantwoordelikhede te vermy en potensiële gesonde interpersoonlike verhoudings en die samelewing te beskadig. Worthington (2009:58) tipeer en beskryf verskillende kategorieë van geregtigheid soos volg:

- Distributiewe geregtigheid probeer om hulpbronne eweredig of billik te versprei (selfs al word dit wat regverdig blyk, nie gelyk verdeel nie). 
- Vergeldende geregtigheid poog om straf uit te deel wat die pyn en lyding eweredig of billik tussen die oortreder en die slagoffer egaliseer of gelykmaak as betaling vir die misdaad.

- Herstellende geregtigheid poog om billike en regverdige oplossings vir maatskaplike onreg te vind deur die betrokkenheid van die slagoffers in die bepaling van hoe om bevrediging vir die oortreding te voorsien sonder om die oortreder uit die gemeenskap te verwyder.

- Prosedurele geregtigheid probeer om billike en regverdige prosesse te spesifiseer vir die hantering van konflik of sake wat potensiële konflik kan veroorsaak.

Onderliggend aan elke kategorieë van geregtigheid is daar 'n wraaksugtige en vergeldende sensasie om met die oortreder en die onreg af te reken. Elke tipe geregtigheid is gemoeid met die aanspreeklikheid, billikheid en verantwoordelikheid van alle partye wat betrokke is en sluit die herstel van gelykheid in na ' $n$ daad wat tot onreg gelei het (Worthington 2009:58).

Onreg kan die behoefte aan wraak en vergelding aktiveer vir die vernedering en pyn wat ervaar word. Dikwels is dit 'n 'oog vir' $n$ oog en ' $n$ tand vir' $n$ tand'-benadering (Eks 21:22-25; Lev 24:19-21; Deut 19:16-21) wat aandring op wraak of vergelding in die najaag van geregtigheid en restitusie. Die 'oog vir 'n oog en 'n tand vir 'n tand'-benadering, of wet van vergelding (lex talionis), is die beginsel dat 'n persoon wat iemand verwond het, in gelyke maat of soortgelyk gedissiplineer word. Die oorsprong van die lex talionis het ontwikkel as 'n regstelsel vir beserings, wrokke en geskille wat die maatskaplike welstand in gemeenskappe bedreig. Die hoofdoel was om onregverdige weerwraak en vergelding te voorkom deur geregverdigde en aanvaarbare geregtigheid te verseker in ooreenstemming en in gelyke maat tot die onreg wat gepleeg is.

\section{Die onreg-gaping}

Geregtigheid en vergifnis kom bymekaar in die onreg-gaping en dryf mense se motivering en vasberadenheid om met geregtigheid of vergifnis te reageer. Worthington (2009:28) beskryf die onreg-gaping soos volg: 'The injustice gap is the ongoing tally we make, rationally or intuitively, that informs us how fair or unfair the outcomes surrounding a transgression are.'

Onreg stimuleer mense se motief tot geregtigheid en vergelding in hul brein en aktiveer hul satisfaksie na wraak en restitusie (vgl. Worthington 2009:64, 2001:35). Herhaalde gedagtes en nadenke oor die onreg of oortreding produseer deurlopende kognitiewe response en emosionele prosesse wat na vore kom uit die oortreding (vgl. Bash 2011:loc. 189). Obsessiewe kognitiewe herinneringe aan die onreg, en gepaardgaande uitputtende emosies kan voortdurend in die kollig wees wanneer mense bewus is van die aanhoudende vergelyking wat hulle trek tussen hul ongelukkige situasie en die onreg wat hulle gely het.
Slagoffers van onreg kan hulself sien as God se vergeldingsinstrumente om geregtigheid deur strafmaatreëls uit te voer of te hoop dat die oortreder deur die owerhede gestraf sal word. Worthington (2009:63) stel dit dat ' $[t]$ he injustice gap yawns and spews out the venom of unforgiving emotions and vengeful motivations.' Die strafmaatreël van weerwraak en vergelding het egter vier funksies (vgl. McCullough 2008:48):

- Dit balanseer 'n morele grootboekrekening

- Dit leer die oortreder 'n les

- Dit bevredig en stimuleer die plesierbane in die brein

- Dit verhoog en versterk die selfbeeld, selfvertroue en bevrediging van die persoon wat die geregtigheid deur vergelding uitvoer.

Mense se reaksie op 'n oortreding van onreg hang van die omvang van die onreg-gaping af. 'n Omvangryke onreggaping word gedryf deur 'n sterker motief vir geregtigheid deur middel van negatiewe emosies van irritasie, woede, bitterheid en wrokke (vgl. Bash 2011:loc. 710). As die gaping voortduur, kan dit tot 'n wraaksugtige motivering lei om woede, skuld en blaam na buite te projekteer en op 'n bepaalde saak of objek te rig (Worthington, Gartner, Jennings, Greer, \& Lin 2013:217; Worthington 2009:62). Afhangende van die oortreding kan spesifieke onreg-gapings geskep word waar misdrywe gedeeltelik onafhanklik van mekaar beskou kan word. 'But the fact is, if an offender repeatedly offends, the same offense is perceived differently the second or the tenth time' (Worthington 2009:62).

Geskiedenis en geheue speel 'n groot rol in die persepsie, introspeksie en ervaring van aanhoudende oortredings, en behels meer restitusie, verskoning en berou (Bash 2011:loc. 467) om die onreg-gaping te verminder, te herstel of op te los. Herinneringe hou mense bevooroordeeld teenoor onreg omdat hulle eie verwonding en lyding meer intens ervaar word as enige pyn wat hulle ander kan aandoen. Mense kan hul emosionele reaksie teenoor die onreg wat ervaar word, verminder deur die volgende aksies te oorweeg, wat nie noodwendig onafhanklik funksioneer nie (vgl. Worthington 2009:62):

- Sosiale optrede soos die aandrang op wraak of die nastreef van vergeldende geregtigheid. Mense kan vergelding verwesenlik deur te sien hoedat die oortreder ly vir die onreg. Sosiale optrede kan verhoudings, in relasionele kontekste, egter ook renoveer deur herstellende geregtigheid, restitusie en die nastreef van sosiaal regverdige voorwaardes om die onreg-gaping te verminder.

- Geestelike dade om die geregtigheid, oordeel en straf van die oortreder aan God oor te laat en te vertrou dat God in beheer is en die oortreder regverdig sal oordeel, of bid vir die oortreder.

- Psigologiese handelinge wat onvergewensgesindheid ontken; projektering van onvergewensgesindheid op 'n ander persoon; kognitief 'n oortreding herformuleer deur verskonings, regverdiging of ontkenning van die onreg; tolereer of aanvaarding van die oortreding; of vergewe. 


\section{Vergifnis en regverdige vergifnis}

Vergifnis is 'n sentrale begrip in die Christendom en die Westerse kultuur wat tevredenheid en vreedsame interpersoonlike verhoudinge tussen mense kan bewaar. Christenskap praat meer van vergifnis as ' $n$ daad van medelye en genade wat aan die oortreder gegee word as die nastreef van vergeldende geregtigheid. Vergifnis in hierdie konteks is 'n geskenk van genade en herinner verwonde mense aan hulle eie behoefte aan goddelike vergifnis en om 'n geloofwaardige lewe in verhouding met God en ander te leef (vgl. Bash 2011:loc. 538, 870). Vergifnis vanuit 'n interpersoonlike perspektief kan gebruik word om pynlike ervarings van onreg aan te raak (Chagigiorgis \& Paivio 2008:123; Freedman, 2008:96). Enright beskryf vergifnis soos volg in 'n uitgebreide definisie:

People, upon rationally determining that they have been unfairly treated, forgive when they willfully abandon resentment and related responses (to which they have a right), and endeavor to respond to the wrongdoer based on the moral principle of beneficence, which may include compassion, unconditional worth, generosity, and moral love (to which the wrongdoer, by nature of the hurtful act or acts, has no right). (Enright 2003:29)

Die omskrywing van vergifnis bevat duidelike kategorieë van argumente en die belangrikste komponente oor wat vergifnis nie is nie (vgl. Denton 2014:17-18; Worthington 2009:74). Vergifnis hou die oortreder verantwoordelik vir die oortreding en behels nie versoening en rekonsiliasie; kwytskelding en regverdiging; kondonering; ontkenning en onderdrukking; om te vergeet; of verdraagsaamheid nie. Hoewel vergifnis ' $n$ voorbereiding is van die aanvaarding dat ' $n$ onreg plaasgevind het, is dit moontlik om vrede te maak en te versoen met die pyn van die verlede, maar nie met die fisiese en emosionele oortreding van die oortreder nie (vgl. Worthington, Greer \& Lin 2011:134).

\section{Tutu beskryf vergifnis soos volg:}

Forgiveness is not forgetting; it's actually remembering remembering and not using your right to hit back. It's a second chance for a new beginning. And the remembering part is particularly important. Especially if you don't want to repeat what happened. (Tutu 1998:5)

Die ervaring van interpersoonlike vergifnis het te doen met die wyse waarop mense mekaar vergewe en behels, volgens Worthington (2009:74), twee verskillende kategorieë van vergifnis. Beslissende en emosionele vergifnis is twee verskillende kategorieë van vergifnis, nie twee verwante prosesse of twee helftes van 'n enkele proses nie: 'We may make a decision to forgive and never feel emotional peace about it' (Worthington 2009:75).

- Beslissende vergifnis kan beskou word as 'n rasionele keuse wat mense maak om te verander en hul gedrag te beheer (Worthington 2009:74; 2003:41). Dit behels ook die etiese verwagtinge wat vereis dat mense opsetlik besluit om te vergewe en nie wraak te neem nie, maar eerder om die verhouding te herstel en die oortreder as'n waardevolle persoon te behandel (vgl. Worthington et al. 2011:134).
- Emosionele vergifnis behels die ervaring van die vervanging van negatiewe onvergewensgesinde emosies met positiewe anders-georiënteerde emosies. Worthington (2009:75; 2003:42) stel dit duidelik dat emosionele vergifnis die fundamenteel belangrikste komponent vir die vergifnisproses is. Dit behels 'n proses waar uitdagende negatiewe emosies soos wraak, wrok, bitterheid, vyandskap, haat, woede en vrees vervang word met positiewe emosies soos empatie, simpatie en liefde (vgl. Worthington et al. 2011:134). Emosionele vergifnis aktiveer barmhartigheids- en genademotiewe wat wraak-, vermydings- en haatdraende motiewe vervang met morele liefde, waartoe die oortreder uit die aard van die onreg geen reg het nie (vgl. Enright 2003:29; Worthington 2009:75).

Die agtergrond van beslissende en emosionele vergifnis hang van die sosiale situasie van die onreg-gebeure af. Emmons (2006:75) beskryf vergifnis as 'n geestelike proses en ontwikkeling met emosie-regulerende eienskappe. Vergifnis word gewoonlik gesien as 'n stadig ontwikkelende proses waar opgehoopte woede 'n begeerte vir vergelding en weerwraak ontwikkel, maar geleidelik deur 'n helingsproses en 'n gevoel van empatie teenoor die oortreder ontlaai. Volgens Chagigiorgis en Paivio (2008:123) behels die voorneme om te vergewe '... reduced negative feelings, increased self-empowerment and self-esteem, and a more differentiated perspective of abusive or neglectful others'.

Deur beslissende vergifnis kan mense doelbewus besluit om te vergewe, selfs wanneer iemand hulle voortdurend verwond. Met verwysing na die sosiale en kulturele agtergrond en betekenis van vergifnis binne die Bybelse leefwêreld dring Levinas (1990:20) daarop aan dat 'n 'horisontale' dimensie van vergifnis tussen mense onontbeerlik 'vertikale' vergifnis van God voorafgaan. Jesus leer sy dissipels om diegene wat ander onregverdig behandel, te vergewe en verbind dit aan die dissipels wat deur God vergewe is: '... en vergeef ons ons oortredings soos ons ook dié vergewe wat teen ons oortree ..." (Matt 6:12) (Bash 2011:loc. 1497). Jesus se aanbeveling is waarskynlik beslissende vergifnis om doelbewus te besluit om iemand te vergewe. 'Later kom Petrus na Jesus toe en vra: "Here, hoeveel keer moet ek my broer vergewe as hy iets verkeerds teen my doen? Selfs sewe keer?" Jesus antwoord Petrus: “Ek sê vir jou, nie sewe keer nie maar selfs sewentig maal sewe keer"' (Matt 6:21-22). Volgens Bash (2011:loc. 1574) en Worthington (2009:77) is dit ' $n$ uitdaging om iemand wat voortdurend onregverdig optree en mense moontlik meer as 'sewentig maal sewe keer' benadeel, ook emosioneel te vergewe.

Vergifnis behels egter ' $n$ proses en nie ' $n$ 'eens-en-vir-altyd' daad of handeling nie (Bash 2011:loc. 1332). Beide beslissende en emosionele vergifnis word moontlik in Lukas 15:11-32 gevind, waar die pa beslissende vergifnis skenk, maar ook dieselfde tipe emosionele vergifnis ondervind wat God se vergifnis kenmerk. Volgens Worthington (2009:78) vereis God beslissende vergifnis en begeer ook emosionele vergifnis. 
Die pa toon juis sy liefde, deernis en 'n jammerte gevoel ( $\dot{\sigma} \sigma \pi \lambda \alpha \gamma \chi v i ́ \sigma \theta \eta)$ vir sy seun, gebaseer op empatie, simpatie en medelye (Lukas 15:20).

\section{Vergifnis verbind met geregtigheid}

Deur die uitdrukking van vergifnis betree mense interpersoonlike-, sosiale en kommunale gebiede van interaktiewe verhoudings in die samelewing. Uitdrukking of nie-uitdrukking van vergifnis is 'n kwessie van hoe en waar die uitdrukking van vergifnis inskakel met die individualistiese (soms eienaardige), sosiale en gemeenskaplike konsep van geregtigheid. Argumentering, sosiale dryfkrag, kulturele waardes en norme, ideologieë, moreel- etiese beginsels en empatie is belangrike komponente om die verhouding tussen geregtigheid en vergifnis te definieer, maar geestelike onderskeiding en godsdienstige oortuigings is onontbeerlik. Worthington (2009:79) verwys soos volg na die onderling verbinding tussen vergifnis en geregtigheid:

- Vergifnis en geregtigheid word deur die onreg-gaping verbind. Wanneer mense verwond is, ervaar hulle intern 'n onreg-gaping wat deur die sosiale en maatskaplike konteks beïnvloed word waarin die oortreding plaasgevind het en hoe mense daarop reageer.

- Vergifnis en geregtigheid word verbind deur persoonlike emosies en motiewe. Die aandrang en nastreef van reg en geregtigheid laat mense met ' $n$ gevoel van restitusie en regverdiging vir die onreg. Die ervaring dat geregtigheid plaasgevind het, bevredig persoonlike motiewe wat mense aktiveer om na die onreg eerder te vergewe en nie vergelding en wraak vir die oortreding na te streef nie. In hierdie proses kan vergifnis positief geassosieer word met sielkundige, fisiese en geestelike gesondheid wat interpersoonlike verhoudings bevorder. Emmons beskryf beide die intra-psigiese en interpersoonlike voordele van vergifnis soos volg:

... forgiveness can activate integrative tendencies in a person, rescuing the psyche from inner conflict and turmoil and transforming the person from a state of fragmentation to a state of integration and from separation to reconciliation. (Emmons 2006:171)

Worthington (2009:82) beskryf ook die wisselwerking tussen geregtigheid en vergifnis soos volg: 'Justice narrows the injustice gap but rarely closes it. Forgiveness can heal the pain within the injustice gap that justice alone did not reduce.' Deur beslissende vergifnis en die ervaring van emosionele vergifnis kan die aandrang en nastreef van retribusie, weerwraak en vergelding vertraag of selfs voorkom en afgeweer word. Geregtigheid en regverdige vergifnis kan mense motiveer om die onreg-gaping en hul aandrang op die regverdiging van vergelding prys te gee.

\section{Geregtigheid en beskeidenheid}

Die aandrang op reg en geregtigheid alleen is nie voldoende om vrede te bring nie (Worthington 2009:72). Mense kan die onreg-gaping oorbrug en besluit om te vergewe wanneer hulle God se liefde en deernis verstaan. In die Evangelies word vergifnis as ' $n$ interpersoonlike morele plig beskryf en in Paulus se geskrifte behels dit 'n morele deug en 'n geskenk van genade (Bash 2011:loc. 2773). Jesus het sy lewe opgeoffer (Fil 2:5-8) en verlos steeds die mens deur onselfsugtige, nederige liefde as die middelpunt van die Christendom te demonstreer. Toe Jesus vir die versoening van die mens se sonde gesterf het, het hy die sondeskuld betaal deur die mens se sonde op hom te neem (Rom 3:24-25; Ef 5:2; Kol 2:13-14; Heb 7:26-27; 10:12:1 Joh 2:2). Bash (2011:loc. 1355) maak tereg die gevolgtrekking dat '... Jesus' death satisfied God's justice'.

Deur begrip en kennis van God se liefde en deernis om te vergewe (Rom 5:10) kan gelowiges meelewend, goedgesind, nederig, sagmoedig en verdraagsaam wees (Kol 3:12-13) om ook te vergewe (vgl. Hägerland 2014:104). Deur genade en deernis (Joh 3:16) vervang God woede met goddelike liefde. Dit behels emosionele vergifnis om volkome te vergewe en motiveer mense om dieselfde vergifnis ook aan ander te gee (2 Kor 1:3-7). God vereis beslissende en emosionele vergifnis (Matt 6:12; 14-15; Luk 6:37-38), en mense is verantwoordbaar as hulle nie vergewe nie. Jesus openbaar en bewys volkome vergewing aan mense (bv. Matt 9:2; Mark 2:5; Luk 05:20) terwyl Hy tot God bid om selfs diegene wat hom kruisig te vergewe (Bash 2011:loc. 316; Worthington 2009:83).

Die mens is egter vol gebreke en tekortkominge en kan nie geregtigheid en liefde perfek uitleef nie, maar hulle word deur God geroep om verantwoordbaar te wees en geregtigheid en liefde te laat triomfeer. Verwonde mense het 'n sterk geregtigheidsmotief, maar as sondaarwesens vergiftig hulle dikwels hul strewe na geregtigheid en word intens gemotiveer deur weerwraak en vergelding om mense te straf wat oortree (vgl. Worthington 2009:70). Die mens se geregtigheidsmotief van vergelding trek dikwels teen die genademotief van God wanneer reg en geregtigheid slegs nagestreef word deur weerwraak en retribusie om met die oortreder af te reken.

\section{Vergifnis 'uit die hart'}

Vergifnis gebeur binne 'n konteks, soos Jesus die besluit om te vergewe in die gelykenis van die onvergewensgesinde amptenaar beskryf (Matt 18:23-35). Onwillig om beslissende vergifnis aan ' $n$ ander medeamptenaar te skenk word die gebrek aan genade en liefde van die onvergewensgesinde amptenaar swaar gestraf (Bash 2011:loc. 1099; Hägerland 2014:70). Gelowiges het 'n morele plig om te vergewe, maar die werklikheid is dat mense soms:

- nie so gou kan vergewe as wat hulle behoort te vergewe nie en koester die onreg wat hulle aangedoen is

- nooit onvoorwaardelik kan vergewe nie

- dink dat hulle ten volle vergewe het, maar later besef hulle het nie vergewe nie

- nie kan of wil vergewe nie. (vgl. Bash 2011:loc. 1522).

God verwag ' $n$ vergewende hart wat verwonding agterlaat en beslissende vergifnis nie net halfhartig skenk nie, maar 
negatiewe emosies vervang met positiewe emosies van liefde, empatie, simpatie en deernis deur emosionele vergifnis te skenk aan die oortreder wat onreg pleeg.

\section{Hantering van onvergewensgesindheid}

Christene word aangespreek om beslissend te vergewe (Matt 6:12), maar sukkel met die ervaring van emosionele vergifnis. Worthington (2009:86-87) wys daarop dat mense die onvergewensgesindheid van onreg verwante gebeure kan verminder deur die volgende te doen:

- Aanvaar die gebeurtenis en beweeg met hul lewens aan.

- Hulle kan die geregtigheid, oordeel en straf van die oortreder aan God oorlaat en hul regte om te veroordeel repudieer en vertrou dat God in beheer is (Gen 18:25; Matt 7:1).

- Hulle kan hulself oortuig dat die oortreding nie so skadelik was soos hulle gedink het nie (Gen 50:20).

- Hulle kan met verloop van tyd leer dat 'n persoon se optrede, wat vermoedelik verkeerd was, volgens die feite regverdig en billik was.

- Hulle kan leer van versagtende omstandighede agter 'n oortreder se aksies wat hulle kan help om die oortreder se optrede te begryp en te vergewe.

- Hulle mag dalk met verloop van tyd vergeet van die oortreding.

- Verdraagsaamheid behels die inhibering van die aanvanklike weerwraak en vergelding en beheer en onderdruk negatiewe emosies en gedrag (Ps 4:4; Ef 4:26; Kol 3:13; Ef 4:1-6). Verdraagsaamheid is egter uitputtend en laat wrok smeulend onder die oppervlak, gereed om te ontvlam wanneer die oortreder weer die persoon verwond.

- Hulle kan probeer geregtigheid kry om die onreg-gaping te verminder (Job 34:12; Jes 56:1-2; Am 5:24; Deut 16:20; Matt 7:1-5). Vergifnis en geregtigheid blyk soms te bots, maar kan ook saam in werking wees.

- Hulle kan hul gevoelens van onvergewensgesindheid verminder wanneer 'n oortreder deur die regstelsel skuldig bevind en gestraf word. Die uitvoering van reg en geregtigheid kan die onreg-gaping en emosionele onvergewensgesindheid verminder en laat afneem.

- Hulle kan natuurlike rampe, verlies, teenspoed en ellende by die oortreder waarneem en glo dat God die oortreder straf (Hand 5:1-11). Waarneming van natuurlike of Goddelike geregtigheid verminder die onreg-gaping waar onvergewensgesindheid verminder, selfs al het emosionele vergifnis nie plaasgevind nie.

- Persoonlike reaksie van die oortreder om die onreg met regverdigheid reg te stel kan ook onvergewensgesindheid verminder. Sonder persoonlike weerwraak en vergelding kan die oortreder die onreg herstel deur 'confessing, repenting, expressing regret, apologising sincerely, offering restitution or punitive damage, or making amends' (Worthington 2009:87-88). Onvergewensgesindheid word hierdeur verminder en die slagoffer ervaar persoonlike geregtigheid en is meer geneig om te vergewe.
Onvergewensgesindheid het 'n negatiewe uitwerking op 'n persoon se fisiese, emosionele en geestelike gesondheid (Minirth \& Meier, 2007:153; Macaskill 2004:29). Wanneer mense nie vergewe nie, word hulle dikwels gevangenes van hul eie emosies van woede, haat en bitterheid (Malcolm, 2008:283; Chagigiorgis \& Paivio 2008:124; Worthington, 2003:68).

\section{Morele dilemmas en konflikte}

Op 'n teologiese en filosofiese vlak skend 'n oortreding die morele orde soos sosiaal bepaal of deur God gestel (Bash 2011:loc. 623). Die verband tussen geregtigheid en vergifnis vereis 'n morele herstel in die proses van weerwraak en vergelding (retribusie) voordat genesing kan plaasvind (Wade, Johnson \& Meyer, 2008:97). Enright en Fitzgibbons (2000:23) stel dat vergifnis in moraliteit gesentreer is, en ' ... on the contrary, when morality is centered in relationships, the self is included'.

Die ervaring van onreg, wat chroniese woede kan handhaaf, beklemtoon die interafhanklikheid van emosie en onvoltooide morele dilemmas. Morele dilemmas en konflikte is 'n integrale deel van die sosiale en morele realiteit van onreg (Bash 2011:loc. 134). Ten spyte van die gebruik van verdedigingsmeganismes kan die sielkundige en morele impak van onreg negatiewe langtermyn-gevolge vir morele ontwikkeling veroorsaak. Wanneer vergifnis egter plaasvind, 'it ceases to be only an act that one performs and becomes part of the moral self' (Enright \& Fitzgibbons 2000:256).

\section{Morele impak van onreg}

Die impak van onreg veroorsaak 'n versteuring in die mens en hul identiteit in 'n gegewe oomblik of situasie. Macaskill beskryf hierdie versteuring van identiteitsvorming deur die verwronge persepsie van 'n onregverdige wêreld soos volg:

Belief in an unjust world may lead individuals to be distrustful of the environment, not always to expect fair treatment and, therefore, to be more accepting of their own and others' transgressions. (Macaskill 2008:43)

Die wêreldbeskouing van verwonde mense verander wanneer hulle die wêreld en hulle omstandighede as onbillik en onregverdig beskou (vgl. Worthington 2009:28; Tangney, Stuewig \& Mashek 2007:351). Die konseptualisering van woede en blaam as tydelike hanteringsmeganismes beskerm hul eie onvoorspelbare wêreld, maar dan weer is woede en blaam die emosionele struikelblokke in die proses om onreg te vergewe (vgl. Macaskill 2008:49-53). Die emosionele energie om woede en blaam in stand te hou dien as 'n afleiding van die pynlike ervaring van onreg en kan die begeerte na vergelding en weerwraak laat toeneem.

Die morele en normatiewe ontwikkeling van verwonde mense kan hul verhouding met God positief of negatief beïnvloed. Dikwels begin mense twyfel, want hulle kan God se goedheid en liefde nie versoen met traumatiese gebeure van onreg in hulle lewens nie (vgl. Worthington et al. 2011:134). 
Die ervaring van onreg kan tot wantroue in God en die kweek van valse verwagtinge teenoor God lei (vgl. Seamands 2004:60). Negatiewe emosies teenoor God kan egter vervang word met positiewe emosies wanneer die ervarings van onreg herevalueer word deur persoonlike gebeure wat die genade, liefde en deernis van God in die verlede demonstreer (vgl. Macaskill 2008:42).

Om te vergewe of nie te vergewe nie is 'n morele keuse waar onvergewensgesindheid vergelding en vermyding aanspoor. Vergifnis kan nie van empatie en narsissisme geskei word nie, want albei het ' $n$ bepalende invloed op verwonde mense om onreg te vergewe (vgl. Macaskill 2004:32; Exline \& Baumeister 2001:133-151). 'n Algemene reaksie op onreg behels herhaalde denke en redenering oor die onreg en ongeregtigheid wat ervaar word.

- Narsissisme kan gekoppel word aan selfgeregtigheid, onvergewensgesindheid en aggressiewe weerstand teen vergifnis (Holeman 2008:253). Mense wat onreg as narsissistiese verwonding ervaar en vergelding, selfregverdiging, bitterheid en woede najaag sal vergifnis moeilik vind (vgl. Macaskill 2004:28).

- Empatie is in die algemeen baie nou verbind aan die positiewe gevolge van vergifnis vir traumatiese gebeure (vgl. Holeman 2008:263). Tangney et al. (2007:362) beskryf empatie as 'n emosionele proses met beduidende implikasies vir morele gedrag. Empatie is die wese van die morele affektiewe sisteem van die mens en behels beide affektiewe en kognitiewe komponente (vgl. Tangney et al 2007:363). Volgens Belicki, Rourke en McCarthy (2008:180) kan individue wat meer empatiese besorgdheid ervaar, dikwels meer verdraagsaam optree teenoor diegene wat hulle verwond het. Die emosie van empatie funksioneer in samewerking met geregtigheid (Worthington 2009:72). Potter-Efron stel dat vergifnis grootliks aangehelp kan word deur empatie

'.. because the forgiver, temporarily at least, make a concerted effort to withdraw from a narcissistic focus on oneself in order to connect with the offender both emotionally and intellectually'. (Potter-Efron 2005:186)

Aan die een kant ervaar mense baie onregte wanneer daar onregverdig teenoor hulle optree word deur die misbruik van mag, maar aan die ander kant tree mense wat onreg ervaar, weer dikwels as onderdrukkers op om ander onreg aan te doen. Deur die bewustheid van hul eie en ander mense se menslike tekortkominge kan mense wat verwond is, begelei word in die proses om onreg te vergewe en die herhaling van weerwraak en vergelding laat vaar. Exline en Zell (2008:249) meld dat: 'If people can see their own limitations or capability for wrongdoing, they should find it easier to forgive others'.

Vergifnis is die ontdekking van die menslikheid in ander ten spyte van traumatiese ervarings van onreg. Mense wat hul sosiale interpersoonlike interaksie wil herstel ten spyte van die sielkundige en morele impak van onreg, kan egter besluit om te vergewe (vgl. Bash 2011:loc. 646). Vergifnis is ' $n$ belangrike komponent in die herstel van verhoudingskonflik wat tot sowel die herstel in verhouding tot die self en ander, as die herontdekking van hoop vir die toekoms kan lei (vgl. Worthington 2009:9). Vergifnis is 'n emosionele, kognitiewe en gedragsproses wat deur die verandering van persepsie, gevoel, houding en gedrag teenoor die oortreder ontwikkel (vgl. Malcolm 2008:283; Worthington 2006:25). Die proses van vergifnis begin wanneer mense hul verwonding deur die impak van onreg erken en eindig wanneer hulle hul negatiewe emosies, gedagtes en gedrag teenoor die oortreder laat vaar.

\section{Die helende krag van regverdige vergifnis, sonder kondonering van onreg}

Sosiale geregtigheid betrek mense wat onregverdige interaksies waarneem en wonde van die verlede tussen groepe, instellings en individue nie vergeet nie. Geregtigheid is in die mens ingebou, maar die nastreef van sosiale geregtigheid en retribusie bring selde vrede aan 'n individu wat afhanklik is van die situasie en die persepsie van elke persoon in die sosiale groep wat onreg beleef (vgl. Worthington 2009:66, 71). In No future without forgiveness skryf Desmond Tutu die volgende oor 'ubuntu' (onderlinge verbondenheid):

A person with $u b u n t u$ has a proper self-assurance that comes from knowing that he or she belongs in a greater whole and is diminished when others are humiliated or diminished, when others are tortured or oppressed, or treated as if they were less than who they are. (Tutu 1999:31)

Die gemeenskap binne 'n bepaalde samelewing kan dit moeilik vind om die impak en gevolge van sosiale onreg te oorkom wanneer onreg ervaar word as die identiteit van'n bepaalde groep in die samelewing of die persoonlikheid van 'n individu wat deur onreg ander verwond. Elke lid van die gemeenskap bewaar, preserveer en handhaaf sy of haar eie persepsie van die onreg-gaping en lewe in verhouding met die gemeenskap se groepsdinamika. Hoewel sosiale en maatskaplike geregtigheid meer mense insluit wie se perspektiewe in berekening gebring moet word, is dit kompleks, aangesien mense in groepe onafhanklike agente is wat dikwels probeer om geregtigheid in hul eie hande te neem. Oortreders se sosiale onreg kan die verdrukte slagoffers se onreg-gaping verskerp, en die ervaring van onreg kan weerstand, retribusie, geweld, vergelding en weerwraak vererger. Dikwels kan gemeenskappe en sosiale groepe geregtigheid uit God se hande neem en selfgeldend optree deur wraakaanvalle, bende-geregtigheid, eermisdade, moorde en bloeddorstige gruweldade en menseslagting deur militante terreurgroepe en rebellemagte.

Die individuele en sosiale onreg-gaping kan geassosieer word met 'negative emotions, self-protective motivations and unconscious evil desires' (Worthington 2009:72). Dikwels dryf " $n$ oog vir 'n oog en 'n tand vir 'n tand'-benadering oormatige retribusie en weerwraak, hoewel mense nie die onreg-gaping kan beëindig deur die onreg selfgeldend te 
hanteer om vrede te herstel nie. Mense is vol gebreke en sondig en kan nie tegelyk geregtigheid en liefde bereik nie (vgl. Worthington et al. 2013:211). Dikwels probeer mense om hul eie gevoelens van onreg uit te skakel deur selfgeldende optrede, maar skep en verplaas eintlik die onreg-gaping weer na ander mense wat dan weerstand kan bied deur geweld en vergelding, of die voorgestelde oplossing vir onreg verwerp deur heftig te protesteer met woede en weerwraak.

Daar is mense wat beweer dat "n oog vir'n oog en 'n tand vir ' $n$ tand'-benadering die beste metode is om onreg te herstel en restitusie te bewerk. Vergifnis antisipeer en poog om die lex talionis en die refleksiewe geneigdheid van die mens tot weerwraak en vergelding - om die oortreder wat deur onreg ander verwond terug te betaal - in toom te hou. In 'n tyd van geweld, konflik en onreg, waar die versoeking voorkom om weerwraak en vergelding as 'n opsie te oorweeg, kan Jesus se onderrig die verskil tussen geregtigheid en vergifnis bepaal. Jesus beveel sy volgelinge: 'Moenie oordeel nie, en oor julle sal nie geoordeel word nie. Moenie veroordeel nie, en julle sal nie veroordeel word nie. Spreek vry, en julle sal vrygespreek word' (Luk 6:37). Vergifnis kan beskryf word as die individu se teenoorgestelde of antitetiese respons op verwonding deur onreg, verdrukking en viktimisasie.

In die Bergrede (Matt 5:38-39) beskryf Jesus die 'oog vir 'n oog en ' $n$ tand vir ' $n$ tand'- benadering in die gemoedere van die wêreld wat nie ware vrede kan bring nie en roep sy volgelinge op om onreg te vergewe eerder as om weerwraak en vergelding na te streef:

Julle het gehoor dat daar gesê is: "'n Oog vir'n oog en 'n tand vir 'n tand." ${ }^{39}$ Maar Ek sê vir julle: Julle moet julle nie teen 'n kwaadwillige mens verset nie. As iemand jou op die regterwang slaan, draai ook die ander wang na hom toe.

Mense kan verwag om 'n oog vir ' $n$ oog en ' $n$ tand vir ' $n$ tand' te betaal, maar die nuwe etiek van die koninkryk van God wat Jesus aanbied (Matt 5,39-42, 44-47; Rom 12:17-21), is nie weerwraak en vergelding nie, maar om alle mense lief te hê, insluitend 'n mens se vyande (Bash 2011:loc. 688). 'n Paar verse later in Matteus (6:12, 14-15) stel Jesus dat mense die oortreder wat deur sy onreg ander verwond, moet vergewe, want om lief te hê omsluit vergifnis. God weet dat mense reg en geregtigheid in hul eie hande wil neem en daarom waarsku Paulus in Romeine 12:17-21:

Moenie kwaad met kwaad vergeld nie. Wees goedgesind teenoor alle mense. ${ }^{18} \mathrm{As}$ dit moontlik is, sover dit van julle afhang, leef in vrede met alle mense. ${ }^{19}$ Moenie self wraak neem nie, geliefdes, maar laat dit oor aan die oordeel van God. Daar staan immers geskrywe: "Dit is mý reg om te straf; Ék sal vergeld," sê die Here. ${ }^{20 "}$ "As jou vyand honger is, gee hom iets om te eet; as hy dors is, gee hom iets om te drink; want deur dit te doen, maak jy hom vuurrooi van skaamte." ${ }^{21}$ Moet jou nie deur die kwaad laat oorwin nie, maar oorwin die kwaad deur die goeie.

\section{Vergifnis is' $n$ handeling}

Beslissende en emosionele vergifnis is afhanklik van die grootte en effek van die onreg-gaping en meer moontlik wanneer die onreg-gaping klein is en die negatiewe emosies geneutraliseer en ontlont word deur positiewe, andersgeoriënteerde emosies (vgl. Worthington et al. 2011:135). Verdraagsaamheid kan wel negatiewe emosies en gedrag onderdruk en ook lei tot persoonlike harmonie en kulmineer in potensiële versoening, maar Worthington meld dat:

It is possible that forbearance can lead to acceptance and (through acceptance) also to personal peace, but forbearance could result in rumination, which will not lead to personal peace. In short, there are several pathways to personal peace, and experiencing emotional forgiveness is one of the most certain. (Worthington 2009:88)

Alhoewel God regverdig is, is God ook genadig en vergewe mense hulle sondes deur genade en deernis (Eks 34:6-7; Rom 5:1; Kol 2:13-14). God het uit genade en liefdevolle deernis die mens deur Jesus se dood aan die kruis vergewe, en Christene aanvaar die belangrikheid van vergifnis as die sentrum van die Christendom. Deur Jesus se onderrig, voorbeeld en opdragte behoort Christene selfs hul vyande te vergewe uit dankbaarheid vir wat God gedoen het. Liefde en dankbaarheid is die reaksie van die Christen op God se genade. Jesus vat die wesenlike van die opdrag van God aan die mens in twee gebooie saam:

Jesus antwoord hom: Jy moet die Here jou God liefhê met jou hele hart en met jou hele siel en met jou hele verstand. Dit is die grootste en die eerste gebod. En die tweede, wat hiermee gelyk staan, is: Jy moet jou naaste liefhê soos jouself. In hierdie twee gebooie is die hele wet en die profete saamgevat. (Matt 22:37-40)

Die essensie van die twee gebooie is 'n konstruktiewe en transformerende wyse van aksie waar mense barmhartig en vergewensgesind teenoor mekaar moet wees; hulle ervaring is dikwels meer in lyn met Petrus se versoek aan Jesus in Matteus 18:21: 'Here, hoeveel keer moet ek my broer vergewe as hy iets verkeerds teen my doen? Selfs sewe keer?' (Worthington 2009:90).

Mense moet vergifnis verstaan en onderskei wanneer hulle nodig het om vergewensgesind te wees, maar ook erken dat hul eie pogings beperk is. Die hoë roeping om onreg te vergewe motiveer mense egter om verskillend te reageer (vgl. Worthington 2009:90):

- Hulle oortuig hulself dat vergifnis nie belangrik is nie.

- Hulle is vinnig om te sê dat hulle vergewe het, maar raak nie werklik ontslae van retribusie en weerwraak nie.

- Hulle werk om te vergewe, maar doen dit om hulself te troos sodat hulle kan sê: 'Kyk wat het ek gedoen!'.

- Hulle werk opreg en ywerig om te vergewe omdat hulle wil verander deur hul gedagtes te vernuwe (Rom 12:2).

Vergifnis is gebaseer op God se vergifnis, en omdat mense in hul eie krag nie in staat is om 'n oortreding regverdig te vergewe nie, kan God mense deur die Heilige Gees tot regverdige vergifnis lei. Vergifnis en geregtigheid kan in balans gehou word deur die verstandhouding dat die mens (slagoffer en oortreder) deur Christus verloste en begenadigde sondaars is. Christene kan regverdige vergifnis in relasionele 
konteks nastreef, terwyl die onderskeid tussen die ervaring van regverdige vergifnis binne die konteks van die sonde en verlossing sonder die kondonering van onreg gehandhaaf word. Christene vergewe nie omdat dit maklik is nie; hulle vergewe omdat hulle hul dankbaarheid openbaar deur op God se genade, liefde en vergifnis te reageer. Worthington beskryf hierdie reaksie van dankbaarheid deur mense wat slagoffers van onreg was, soos volg aan te moedig:

We put off this old, sinful nature by fighting against it (Rm 6:1-4, 12-14; Gl 5:19-21; Col 3:5-11). We likewise must forbear, forgive and seek justice. By doing so, we put on a new, redeemed nature (Rm 6:5-11, 17-19; Gl 5:22-26; Col 3:12-17). This battle is not winnable by independent human effort (Rm 7:14-24). We can only win by cooperating with God (Rm 7:25-8:11; Eph 2:8-10; Phil 2:12-13). (Worthington 2009:91)

Die helende krag van regverdige vergifnis is ' $n$ alternatief vir die ervaring van onreg. Die navorsing van McCullough, Root, Tabak en Witvliet (2009:427), Lawler-Row en Reed (2008:75), Malcolm (2008:288); Browning, Reed, Browning en Fowler (2004:64) en Ransley en Spy (2004:49) het getoon dat vergifnis positief geassosieer kan word met psigologiese en fisiese gesondheid, positiewe emosies (as 'n alternatief vir angs, depressie, woede en bitterheid), gesonde sosiale interaksie en hoë lewenstevredenheid. Harris (2007:128) beskryf die positiewe impak van vergifnis soos volg: '... to improve one's health and satisfaction with life, raise optimism, and increase the ability to connect with others.' Die navorsing van Lawler-Row en Reed het ook die volgende gevind:

... individuals have better levels of health, show more moderate physiological responses when recalling interpersonal conflict, have better relationships with others, and exhibit less stress and higher levels of spirituality. (Lawler-Row en Reed 2008:87)

Vergifnis en geregtigheid beïnvloed mekaar op die wyse waarmee God met mense handel en mense onderling teenoor mekaar optree (Worthington 2009:28). Mense wat deur onreg verwond is, kan God se agente vir liefde en regverdigheid wees, maar kan nie in hul eie krag vergewe nie; hulle moet erken dat slegs God volkome regverdig en genadig is en hulle moet streef om te leef volgens Christus se opdrag: Om eerstens die Here God lief te hê met hulle hele hart, siel en verstand; en om tweedens hul naaste lief te hê soos hulself (Mark 12:30-31) (Bash 2011: loc. 571). Worthington wys op die volgende:

Yet completely unconstrained forgiveness is an ideal. We are to forgive like God forgives (Col 3:13), but we are only image bearers of God - bearers of the imago Dei - not God ourselves. (Worthington 2009: 36)

Alhoewel vergifnis ' $n$ daad van geloof en 'n gelowige se reaksie is teenoor ' $n$ oortreder wat deur onreg verwond, moet dit gesien word as 'n religieuse proses van geregtigheid en nie ' $n$ kitsoplossing om die onreg te herstel deur kondonering nie. Volgens Ransley en Spy (2004:15) is die rasionele doel en proses van vergifnis '... to imitate God, to fulfill one's religious duty, to seek God's forgiveness, to follow the path of righteousness, to repair relationships'. Verwonde mense moet toegee dat hulle nie deur hul eie krag regverdige vergifnis aan die oortreder kan skenk sonder kondonering van onreg nie. Dit behels dat mense wat deur onreg verwond is, pretensieloos en afhanklik van die Heilige Gees moet wees vir leiding en wysheid.

Regverdige vergifnis kan nie met gebalde vuiste vasgegryp word en die onreg deur restitusie kondoneer nie, 'but only by an on-your-knees, openhanded attitude receptive to mercy, grace and love' (vgl. Worthington 2009:91). Hierdie ingesteldheid teenoor 'n oortreder wat deur onreg verwond, maak die verwonde mens weer bewus van Romeine 3:23-26:

Almal het gesondig, en het nie deel aan die heerlikheid van God nie, maar hulle word, sonder dat hulle dit verdien, op grond van sy genade vrygespreek vanweë die verlossing deur Jesus Christus. Hom het God gegee as offer wat deur sy bloed versoening bewerk het vir dié wat glo. Hierdeur het God getoon wat sy vryspraak behels: Hy het die sondes wat Hy voorheen in sy verdraagsaamheid tydelik ongestraf laat bly het, vergewe. Maar Hy het ook getoon wat sy vryspraak in die teenswoordige tyd behels: Hy oordeel regverdig deurdat Hy elkeen vryspreek wat in Jesus glo.

\section{Vergifnis en die nastreef van Christelike etiek}

In Kolossense (13:13) praat Paulus van sowel vergifnis as meelewendheid, goedgesindheid,nederigheid, sagmoedigheid en verdraagsaamheid en dring daarop aan dat die Kolossense mekaar vergewe (Bash 2011:loc. 956). Die betekenis van vergifnis is deel van 'n bundel deugde wat te doen het met hoe mense in 'n gemeenskap met mekaar oor die weg kan kom. Vergifnis in hierdie konteks verwys na hoe mense op 'n morele oortreding, soos onreg, en die hantering van mense se irriterende swakhede, foute en gedrag reageer. Bash beskryf die etiese optrede van gelowiges soos volg:

One of the achievements of Christian ethics has been to extend the idea of forgiveness from being only vertical in scope (i.e. from God to human beings) to being also horizontal (from human being to human being). Bash (2011:loc. 2846)

Jesus kombineer die vertikale en horisontale uitdrukking van vergifnis en verkondig God se vergifnis aan alle mense (vgl. Fortune \& Marshall 2004:32). In die Nuwe Testament is daar verskillende metafore en vergelykings wat gebruik kan word om te verduidelik wat dit vir mense beteken om mekaar te vergewe. Om te vergewe behels om 'n geskenk te gee, of om nie woede, bitterheid en die dors na retribusie en weerwraak na te streef nie.

In die herstel- en genesingsproses kan verwonde mense met hul lewens voortgaan en stappe doen om te verseker dat die helende krag van regverdige vergifnis hul negatiewe en pynlike emosies herstel. Dit is slegs deur pretensieloosheid dat daar die moontlikheid van persoonlike, sosiale en maatskaplike vrede is, waar mense genade kan betoon, kan liefhê, vergewe en vir geregtigheid kan werk (vgl. Worthington 2009:35). Christen-gelowiges kan regverdige vergifnis in relasionele konteks nastreef, terwyl die ervaring van regverdige vergifnis 
binne die konteks van die sonde en verlossing, sonder kondonering van onreg, plaasvind. Vergifnis is nie net 'n daad om onregverdige mense vry te stel nie, maar bring ook genesing en vrede in mense se harte vir die onreg wat hulle aangedoen is (Bash 2011:loc. 1302). Jesus gee die versekering in Matteus 6:14: 'As julle ander mense hulle oortredings vergewe, sal julle hemelse Vader julle ook vergewe.' Dit beteken nie dat verwonde persone hulself nie mag verdedig nie, maar dat die wyse waarop reageer word wanneer daar persoonlik onreg is, deel van hul dankbaarheid sal wees vir God se genade, liefde en deernis.

\section{Samevatting}

Mense ervaar onreg wat pyn en diep wonde kan veroorsaak, maar hulle kan ook liefde bewys, genadig wees, vergewe en na reg en geregtigheid streef. Desmond Tutu (1999) stel dat daar 'geen toekoms sonder vergifnis is nie, maar vermoedelik is daar ook geen vergifnis sonder geregtigheid nie. Vergifnis moet regverdig wees, en die verwonde persoon kan vir die belydenis, berou en herstel van die onreg vra. As vergifnis ook geregtigheid behels, word belydenis, berou en herstel fundamentele vereistes en nie opsioneel nie (Bash 2011:loc. 2821). Berou kan nie die oortreding of die morele gevolge van onreg ongedaan maak nie, maar dit kan wel beskadigde relasionele verhoudings en die onreg regstel. Die oortreder kan probeer om die oorsaak en gevolge van die oortreding te herstel en so 'n proses begin wat sowel die relasionele verwonding genees as die morele gevolge van die onreg of oortreding verwyder (Bash 2011:loc. 2832).

Vergifnis kan gedefinieer word as 'n religieuse proses van geregtigheid wat, ten spyte van die pyn en onreg wat gely is, negatiewe gedagtes, gevoelens en intensies van vergelding en weerwraak kan ontlaai deur 'n morele (en geestelike) daad waar die oortreder vrygestel word aan die oordeel en genade van God. 'n Obsessie en konstante fokus op die onreg wat gepleeg is, veroorsaak onnodige pyn. Vergifnis is 'n keuse van óf 'n pad van bitterheid en weerwraak, óf om 'n pad van vryheid waar ' $n$ herstel-ervaring betree word om die pyn van onreg te verwerk. Die Bybel toon dat vergifnis nie net relevant is in die God-mens-verhouding nie, maar ook in interpersoonlike verhoudings. Wanneer slagoffers vergewe, volg hulle Jesus se voorbeeld om mense hulle oortredinge en ongeregtigheid te vergewe.

Vergifnis is ' $n$ emosionele verligting en bevryding van die slawerny aan die verlede, maar nie 'n poging om die werklikheid van die verlede te vergeet nie. Dit is ' $n$ keuse om ten spyte van pyn en onreg weerwraak en vergelding op te gee en hoop vir die toekoms te herstel.

Die Here Jesus se gebed (Matt 6:9-15) is gebaseer op die veronderstelling dat mense hulself en ander se onvolmaaktheid moet aanvaar en ander voor God moet vergewe om soortgelyke vergifnis te ontvang ten einde self vergifnis te ervaar. Die Bybel wys daarop dat goddelike vergifnis 'n motivering vir onvoorwaardelike interpersoonlike vergifnis is (Matt 6:12; 18:21-22). Vergifnis impliseer die Christelike plig om ander mense te vergewe en dui op 'n lewe wat vergifnis uitstraal (France, 2007:250; McMinn, 1996:214). Uit 'n Bybelse perspektief is interpersoonlike vergifnis 'n Goddelike opdrag aan gelowiges (Matt 5:38-48; 6:12; 14; 18:21-35; Luk 6:27-37; 11:4; 17:3-4; 23:34; Ef 4:32; Kol 3:13; Jak 5:13-16). Net soos die gelowige sonder voorwaarde of verwyt vergifnis ontvang (Jes 1:18; Jer 3:22; Heb 8:12; 1 Joh 1:7-10), moet dit ook gegee word aan ander mense uit dankbaarheid vir persoonlike verlossing. Vergifnis kan nie verwag word as daar nie ' $n$ bereidwilligheid is om ook vergifnis aan ander te gee nie (Matt 5:23-24; 6:12; 14-15; 18:35; Mark 5:25; 11:25-26; Luk 6:37; 11:4: 17:3).

Vergifnis is gebaseer op God se verlossing deur genade, barmhartigheid en deernis, terwyl die mens geneig is om beide te vergewe en geregtigheid sonder verskoning vir onreg na te streef. Die mens is nie deur hul eie krag in staat om 'n oortreding of onreg regverdig te vergewe nie, maar God kan mense deur die Heilige Gees tot regverdige vergifnis lei. Vergifnis en geregtigheid kan in balans gehou word met die verstandhouding dat die mens (slagoffer en oortreder) deur Christus verloste en begenadigde sondaars is. Christengelowiges kan regverdige vergifnis in relasionele konteks nastreef, terwyl die ervaring van regverdige vergifnis binne die konteks van sonde en verlossing sonder kondonering van onreg plaasvind. Vergifnis is nie net 'n daad om onregverdige mense vry te stel nie, maar bring ook genesing en vrede in verwonde mense se harte vir die onreg wat hulle aangedoen is. Vergifnis kan gedefinieer word as die onvoorwaardelike aanvaarding van God se genade en deernis en die vrystelling (oorgawe) van retribusie, weerwraak, vergelding en onreg (selfs die oortreder) aan die genade en oordeel van God.

\section{Erkenning Mededingende belange}

Die outeur verklaar dat hy geen finansiële of persoonlike verbintenis het met enige party wat hom nadelig kon beïnvloed het in die skryf van hierdie artikel nie.

\section{Literatuurverwysings}

Bash, A., 2011, Just forgiveness. Exploring the Bible, weighing the issues, J.F. Print, London, UK, [Kindle issue] Available: http://www.amazon.com

Belicki, K., Rourke, J. \& McCarthy, M., 2008, 'Potential dangers of empathy and related conundrums', in W. Malcolm, N. DeCourville \& K. Belicki (eds.), Woman's reflections on the complexities of forgiveness, pp. 165-185, Routledge, New York, ny.

Browning, R.L., Reed, R.A., Browning, D.S. \& Fowler, J.W., 2004, Forgiveness, Reconciliation, and Moral Courage: Motives and Designs for Ministry in a Troubled World, Studies in Practical Theology, Eerdmans Publishing Company, Cambridge.
W.

Chagigiorgis, H. \& Paivio, S., 2008, 'Forgiveness as an outcome in Emotion-Focused Trauma therapy', in W. Malcolm, N. DeCourville \& K. Belicki (eds.), Woman's reflections on the complexities of forgiveness, pp. 121-141, Routledge, New York, NY.

Denton, R.A., 2014, 'Utilizing forgiveness to help sexually abused adolescents break free from guilt and shame: A pastoral Gestalt theory', Acta Theologica 34(2), 5-28.

Emmons, R.A., 2006, 'Spirituality: Recent progress', in M. Csikszentmihalyi \& I.S. Csikszentmihalyi, (eds.), A life worth living: Contributions to positive psychology, pp. 62-81, Oxford University Press, New York, NY.

Enright, R.D., 2003, Forgiveness is a choice. A step-by-step process for resolving anger and restoring hope, United Book Press, Baltimore, MD.

Enright, R.D. \& Fitzgibbons, R.P., 2000, Helping clients forgive: An empirical guide for resolving anger and restoring hope, American Psychological Association, Washington, DC 
Exline, J.J. \& Baumeister, R.F., 2001, 'Expressing forgiveness and repentance', in M.E. McCullough, K.I. Pargament \& C.E. Thoresen, (eds.), Forgiveness. Theory, research and practice, pp. 133-155, Guilford Press, New York.

Exline, J.J. \& Zell, A.L., 2008, 'Does a humble attitude promote forgiveness? Challenges, caveats and sex differences', in W. Malcolm, N. DeCourville \& K. Belicki (eds.), Woman's reflections on the complexities of forgiveness, pp. 235-251, Routledge, New York, NY.

Fortune, M.M. \& Marshall, J.L. (eds.), 2004, Forgiveness and abuse: Jewish and Christian reflections, Routledge, London.

France, R. T., 2007, The gospel of Matthew, Eerdmans Publishing Company, Grand Rapids, MI.

Freedman, S., 2008, 'Forgiveness education with at-risk adolescents. A case study analysis', in W. Malcolm, N. DeCourville \& K. Belicki (eds.), Woman's reflections on the complexities of forgiveness, pp. 93-119, Routledge, New York.

Hägerland, T., 2014, Jesus and the forgiveness of sins. An aspect of His prophetic mission, Cambridge University Press, New York, NY. (Society for New Testament studies, Monograph series 150)

Harris, E.S., 2007, 'Response to commentaries: Working with forgiveness in Gestalt Therapy', Gestalt Review, 11(2), 127-129.

Holeman, T.V., 2008, 'Repentance in intimate relationships', in W. Malcolm, N. DeCourville \& K. Belicki (eds.), Woman's reflections on the complexities of forgiveness, pp. 253-274, Routledge, New York, NY

Lawler-Row, K.A. \& Reed, K.A., 2008, 'Forgiveness and health in women', in W. Malcolm, N. DeCourville \& K. Belicki (eds.), Woman's reflections on the complexities of forgiveness, pp. 75-91, Routledge, New York, NY.

Levinas, E, 1990, Difficult freedom: Essays on Judaism, Johns Hopkins University, Baltimore, MD.

Malcolm, W., 2008, 'The timeliness of forgiveness interventions', in W. Malcolm, N. DeCourville \& K. Belicki (eds.), Woman's reflections on the complexities of forgiveness, pp. 275-292, Routledge, New York, NY.

Macaskill, A., 2004, 'The treatment of forgiveness in counselling and therapy', Counselling Psychology Review 20, 26-33.

Macaskill, A., 2008, 'Just-world beliefs and forgiveness in men and women', in W. Malcolm, N. DeCourville \& K. Belicki (eds.), Woman's reflections on the complexities of forgiveness, pp. 39-59, Routledge, New York, NY.

McCullough, M.E., 2008, Beyond revenge: The evolution of the forgiveness instinct, Jossey-Bass, San Francisco, CA.
McCullough, M. E., Root, L. M., Tabak, B. \& Witvliet, C., 2009, 'Forgiveness', in S.J. Lopez \& C.R. Snyder (eds.), Oxford Handbook of Positive Psychology (2nd ed.), pp. 427-435, Oxford, New York, NY.

McMinn, M. R., 1996, Psychology, theology and spirituality in Christian counseling, Tyndale House Publishing, Wheaton, IL.

Minirth, F.B. \& Meier, P.D., 2007, Happiness is a choice, Baker Book House, Grand Rapids, MI.

Potter-Efron, R.T., 2005, Handbook of anger mangement: Individual, couple, family, and group approaches, Haworth Press, Binghamton, NY.

Ransley, C. \& Spy, T. (eds.), 2004, Forgiveness and the healing process: A central therapeutic concern, Brunner-Routledge, New York, NY.

Seamands, D.A., 2004, Genesing van emosionele pyn - nuwe hoop vir mense wat seer gekry het, CUM Boeke, Vereeniging.

Tangney, J.P., Stuewig, J. \& Mashek, D.F., 2007, 'Moral emotions and moral behavior', Annual Review of Psychology 58, 345-372.

Tutu, D., 1998, Without forgiveness there is no future, Rider Books, London, UK.

Tutu, D., 1999, No future without forgiveness, Rider Books, London, UK.

Wade, N.G., Johnson, C.V. \& Meyer, J.E., 2008, 'Understanding concerns about interventions to promote forgiveness: A review of the literature', Psychotherapy: Theory, Research, Practice, Training 45, (1), 88-102.

Worthington, E.L., 2001, Five steps to forgiveness: The art and science of forgiving, Crown Publishers, New York, NY.

Worthington, E.L., 2003, Forgiving and reconcilng, InterVarsity Press, Downers Grove, IL.

Worthington, E.L., 2006, Forgiveness and Reconciliation: Theory and Application, Brunner-Routledge, New York, NY.

Worthington, E.L., 2009, A just forgiveness: responsible healing without excusing injustice, InterVarsity Press, Downers Grove, IL.

Worthington, E.L., Greer, C.L. \& Lin, Y., 2011, 'Forgiveness', in T. Clinton \& R. Hawkins (eds.), The popular encyclopedia of Christian counseling: An indispensable tool for helping people with their problems, pp. 134-136, Harvest House Publishing, Eugene, Oregon.

Worthington, E.L., Gartner, A.L., Jennings, D.J., Greer, C.L. \& Lin, Y., 2013, ‘How God comes near and transforms us through forgiveness', in D.W., Appleby \& G. Ohlschlager (eds.), Transformative encounters. The intervention of God in Christian counselling and pastoral care, pp. 211-226, InterVarsity Press, Downers Grove, IL. 